\title{
Propositions and Suggestions Addressed to Implement the Provisions of the Russian Federal Law No 217
}

\author{
I.S. Bulnina \\ L.I. Askhatova \\ Kazan (Volga region) Federal University, 18, Kremlyovskaya Street, Kazan, \\ Repablic of Tatarstan, Russian Federation, 420008
}

Doi:10.5901/mjss.2014.v5n18p129

\begin{abstract}
The article considers the Provisions of the 2nd August 2009 Federal Law No 217. The author points out a number of aspects that need to beimplemented in order to increase the attractiveness of the academic and technical developments of higher educational institutions and national academies for the potential partners. The principal organizational scheme of cooperation between the participants of the process of creating a smaller innovative company has been suggested.
\end{abstract}

Keywords: Federal Law No 217, intellectual property rights, smaller innovative companies, know-how, innovation policy.

\section{Introduction}

In 2009, the Federal law regulating the procedures of creating smaller innovative companies within the limits of the state organizations in the academic sphere and the sphere of higher education was passed.

The mechanism of the innovation policy activation in Russia, based on the development of the innovative forms, suggests the increase of practical application of the developments of Research and Development institutions. Ensuring the growth of the number of developments in the sphere of economics dealing with the material and non-material goods and services serves as the basis for the expansion of the Russian research-intensive production $[1,5]$.

It is suggested that the application of the cited above federal law will contribute to the accomplishing of manynational economy tasks, such as:

1. Ensuring the optimal conditions for the introduction of the new technologies and techniques into the country's economy.

2. Creating the conditions for simplification of technologies' transfer from the sphere of science into the industry [4].

3. Pointing out the perspective branches of the Research and Development activities in the state organizations, as well as in other institutions dealing with science and education.

Financial side also plays an important role in the necessity of smaller forms activation in the innovation sphere. As a rule, the expenses spent on the creation of a new project or technology are less than those spent on the research executed by a large company $[2,8]$.

There is a scientific and technical beginning in the organizations and institutions in the spheres of science and education to be turned into life in the near future. The conditions to attract well-qualified researchers into the innovative processes are being created. The state supports these processes in the conditions of the market economy [12].

\section{Theory}

The research and implementation of the $2^{\text {nd }}$ August 2009 Federal Law No 217 provisions are the important conditions of the development of the innovative sphere. Already the name of the Federal law reflects the topical questions of the innovation policy development [3]. Among them are:

1. Corporate personhoods together with other market participants have received the right to create budget scientific institutions without getting an approval from the federal executive organs.

2. Corporate personhoods' activities include the introduction of the developments of Research and Development institutions into the industrial and commercial practice, whereas the exclusive rights to these developments 
belong to the Research and Development institutions.

3. Corporate personhood's authorized capital should contain the right to the object of intellectual property, whereas the exclusive rights to this object belong to the respective institutions. At the same time, the authorized capital obtains the right to use the object of intellectual property through the conclusion of the licensed treaty after the corporate personhood's registration.

4. The list of intellectual property objects has been established. According to the licensed treaty, it can serve as an investment into the corporate personhood's authorized capital.

5. In case of the involvement of partners into the creation of a corporate personhood, a scientific or educational institution's share should correspond to the blockingstake.

\section{Results}

The above mentioned conditions of the innovation policy implementation have to be elaborated further on. First of all, the exclusive rights to research that belong to the corresponding organizations should be distinguished. After the creation of a corporate personhood, the researcher's right on the investment, i.e. an object of intellectual property, passes on to the created company.

Secondly, the right to use the object of intellectual property in the authorized capital after the corporate personhood registration in the unified state list of corporal personhoods should be considered. The resulted situation should be solved from a modern perspective. The transition onto the created corporate personhood of the right to use provokes a risk for the potential partner to cover the expenses spent on the creation of the corporal personhood which does not have the right to the technology in its authorized capital. The situation when the rights are never passed further on is possible. In our opinion, there should be economical and legal mechanisms that would guarantee the investment of the right to the technology for the potential partner.

Thirdly, the industrial secrets (know-how) are under no legal protection. It cannot be legally registered, either. In this connection, the question is how to attract the investor without the revelation of the new technology's secret $[1,9]$. The mechanisms of the know-how protection should be developed as well.

In terms of the partners' attraction, there is a practical necessity to protect the interests and rights of the researcher. The protection should carry a complex character.

The corporal personhood's economical activities should also be taken into consideration due to their limiting character. These problems should be solved in the near future.

According to the Unified Budget Accounting Guide, approved by the Minister of Finance of Russian Federation on the $30^{\text {th }}$ of December 2008 in the precept No 148 n (registered in the Justice Ministry of Russian Federation on the $12^{\text {th }}$ of February 2009, No 13309), the organization dealing with the research has all the rights on the objects of intellectual property. When these objects are transferred to the budget accounting, their price depends on the expenses spent on their creation (purchase). The situation where the investor's share is defined depending on the sum of money necessary for the practical implementation of the development comes forward. The investment sum is usually much bigger than the researcher's share in the corporal personhood's authorized capital. This does not allow the researcher to keep the blocking stake $[7,8,11]$.

It is worth to evaluate the rights on the objects of intellectual property. It is assumed that practically any development would be evaluated as more than five thousand rubles. This allows one to attract an independent expert for the evaluation. In this case, a potential partner (investor) has to accept the evaluation, so that the scientific or educational organization could keep the blocking stake. At the same time, according to the rules of the accountancy and the tax account transcripts, depreciation expense will be allocated only to cover the expenses spent on the research of a development [10].

When the right to use a development is transferred to a corporal personhood, according to the licensed treaty, a number of the aspects should be taken into consideration:

1. The license should be urgent and unexclusive.

2. The expenses of the patent support should be stated in the licensed treaty in order to minimize the researcher's expenses.

3. In order to attract an investor, a researcher should make the investment in the creation of a corporal personhood based on the research license, the latest - at the moment of registration.

The model below represents a principal organizational scheme of interaction between the participants ofinnovative process (pic.1): 


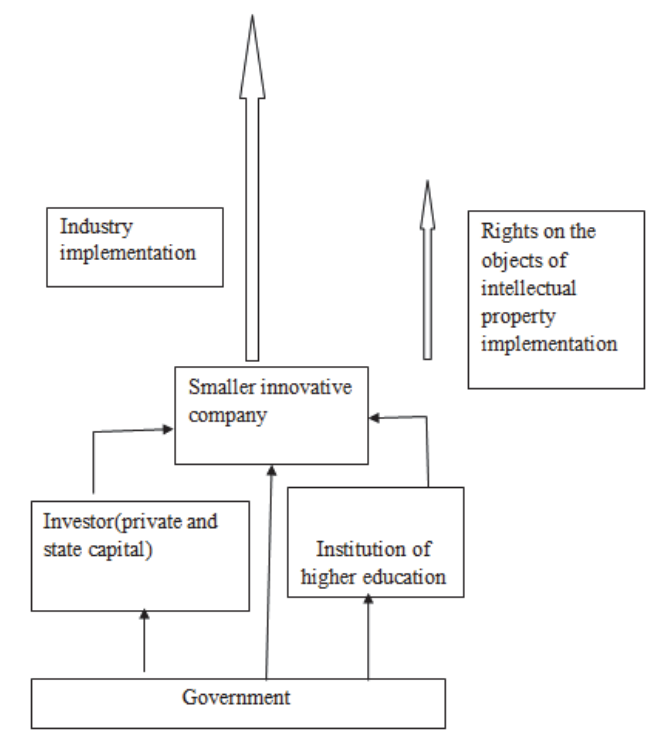

Pic. 1 - Principal organizational scheme of interaction between the participants of innovative process that deals with the creation and development of a smaller innovative company.

\section{Conclusions}

As for the development of the innovation policy basics, the model of the interaction between the investor and the institution of higher education should be improved. The model is suggested in the scientific research $[2,14,15]$. Its configurations are based on the contemporary provisions, as well as the appearance of the state's regulatory function in terms of the potential partners of the institutions of higher education, a new corporal personhood's creation and the creation of a smaller innovative company. The effectiveness of the structure of the participants' interaction is achieved through the exclusion of organizations responsible for innovative research promotion [6].

In the suggested model, the government has a legislative and a regulative function. The investor, the institutions of higher education and the Research and Development are the smaller innovative company's co-founders [13].

Thus, a scientific or educational organization forms its two sources of income: the implementation of scientific production and the actualization of the rights on the objects of intellectual property.

In our opinion, the income gathered from the corporal personhood's authorized capital shares should become the scientific and education institutions'. It should further on be directed to guard the rights on the objects of intellectual property, serve as the authors' reward payments, as well as support its core activities.

In order to successfully implement the main provisionsof the 2nd August 2009 Federal Law No 217, a number of economic mechanisms should be implemented. To solve the problems mentioned above, the institutions of higher education and research institutes' regulations should be changed. It will allow to increase the attractiveness of the developments for the potential partners of the scientific and educational organizations; create the basement for the further development of the scientific and technical beginning, according to the market demand; and solve the topical problems connected to the improvement of the industry effectiveness, such as the raise of the import substituting technologies and a better quality and competitiveness of the Russian production on the market.

\section{References}

Maria Joao Magarro.Archives and education.The construction of educational memory.// Sisifo : Educational Sciences Journal, Iss 01, Pp $73-84$ (2008)

Padula, M. (2003). A comprehensive look at online student support services for distance learners//American Journal of Distance Education, 17(2). 119-128. doi: 10.1207/S15389286AJDE1702_4

Averianov, B.A., Bagautdinova, N.G., Sarkin, A.V. Estimation of manufacturing enterprise development risks in process of operational activity // World Applied Sciences Journal, 27(13), 2013, 202-206. 
Kirshin I.A., Datsyk A.A., Titov A.V. Forecasting the Dynamics of an Innovative Cycle. - World Applied Sciences Journal (Economics, Management and Finance). - 2013. - №27. - P. 197 - 201.

Glebova I.S., Sadyrtdinov R. and Rodnyansky D. Impact Analysis of Investment Attractiveness of the Republic of Tatarstan on Fixed Investments of its Leading Companies // World Applied Sciences Journal 26 (7): 911-916, 2013.

Sarkin, A.V., Bagautdinova, N.G., Fazlieva, E.P., Averianov, B.A. Development and implementation of machinery building enterprises complex development strategies in the contexts of the contemporary Russian economy institutes // World Applied Sciences Journal, 27(13), 2013, 174-179.

Safiullin M.R., Elshin L.A., Shakirova A.I., Ermolaeva P.O., Prygunova M.I. (2013). Influence of Territorial Ecological Load Factors on Social and Economic Well-Being of Population: Methodology Development and Econometric Model Construction. World Applied Sciences Journal 25, 7, 1057-1061.

Srinivas, Krishna Ravi, Intellectual property rights and bio commons: open source and beyond. //International Social Science Journal, 58, Pp319-334 (2006)

Isaeva, T.N., Safiullin, L.N., Bagautdinova, N.G., Shaidullin, R.N. Aspects of a multi-level study of competitive performance of objects and subjects of economic management // World Applied Sciences Journal, 27(13), 2013, 116-119.

Gainova R.A., Shaidullin R.N., Safiullin L.N. and Maratkanova E.M. Infrastructural Component in Maintenance of Competitiveness of Region// World Applied Sciences Journal, 27(13), 2013, pp. 97-101.

Freeman, J., 2003. Extending public law norms through privatization. //Harvard Law Review, 116, Pp 1285-1352.

Tapinos, E.; Dyson, R. and Meadows, M. ,2005, The impact of performance measurement in strategic planning/International Journal of Productivity and Performance Management, Vol. 54, No. 5/6, pp. 370-384.

Commission of European Communities, 'The Role of Universities in the Europe of Knowledge', 2003// Communication from the Commission, Brussels, February 2, 2003, COM(2003)58 final.

Douglas, J. and Douglas, A., 'Evaluating Teaching Quality', 2006//Quality in Higher Education, vol. 12, no. 1, pp. 3-13.

Anderson G., 'Assuring Quality Resisting Quality Assurance: Academics' Responses to "Quality" in some Australian Universities', 2006//Quality in Higher Education, vol. 12, no. 2, pp. 161-173. 